\title{
PELATIHAN DETEKSI TUMBUH KEMBANG ANAK PADA KADER POSYANDU PONOWAREN GAMPING SLEMAN
}

\section{THE GROWTH DEVELOPMENT CHILD TRAINING OF POSYANDU CADRES AT PONOWAREN GAMPING SLEMAN}

\section{${ }^{1)}$ Ellyda Rizki Wijhati ${ }^{2)}$ Suharni ${ }^{3)}$ Budi Susilawati}

${ }^{1,2,3)}$ Prodi DIII Kebidanan Fakultas Ilmu Kesehatan Universitas 'Aisyiyah Yogyakarta

Jl. Ring Road Barat 63 Mlangi Nogotirto Gamping Sleman 55292 Daerah Istimewa Yogyakarta email: ewijhati@ymail.com

\begin{abstract}
ABSTRAK
Masa balita merupakah periode emas pertumbuhan dan perkembangan yang sangat penting dan menentukan kualitas hidup anak mendatang. Deteksi pertumbuhan dan perkembangan pada masa balita sangatlah penting dilakukan untuk memantau apakah terjadi penyimpangan pada proses tumbuh kembang anak, Deteksi tumbuh kembang Balita (DTKB) yang dilakukanlebih awal dapat menemukan penyimpangan lebih dini,sehingga intervensi yang diberikan akan jauh lebih efektif dan efisien. Pelaksanaan Posyandu Kuncup Mekar di Ponowaren Sleman lebih banyak melakukan pemantauan pertumbuhan, sedangkan pemantauan perkembangan hanya dilakukan jika ada kunjungan dari Puskesmas, karena terbatasnya kader yang pernah mengikuti pelatihan DTKB. Tujuan Pelatihan DTKB ini adalah meningkatkan kemampuan kader untuk mampu melakukan DTKB dengan benar. Metode Pelatihan yang dilakukan meliputi uji pre dan post tes pelatihan, penyuluhan DTKB, Praktik DTKB meliputi pengukuran antropometri, pengisian buku KIA pada lembar Kartu Menuju Sehat (KMS), table z-score, Lingkar Kepala, interpretasi hasil penilaian DTKB dan penyuluhan pemanfaatan buku KIA sebagai media pendidikan kesehatan. Hasil pengabdian ada kenaikan tingkat pengetahuan tentang tumbuh kembang anak dibuktikan dengan kenaikan skor nilai prepost test sebanyak 10-30 point, 14 kader telah mengikuti pelatihan DTKB dan telah mampu mempraktikkan DTKB dengan benar, buku KIA tidak hanya digunakan untuk mencatat hasil pengukuran pertumbuhan namun juga mencatat hasil deteksi perkembangan dan digunakan sebagai media pendidikan kesehatan oleh kader.
\end{abstract}

Kata Kunci: Balita, Pertumbuhan, Perkembangan, Kader

\section{ABSTRACT}

The toddler is a golden period of growth and development that is very important and determines the quality of life of the upcoming future. Detection of growth and development in childhood can detect what happens, early Toddler Growth and Development Detection (TGDD) can find early uniformity, soo the intervention will be more effective and efficient. Implementation Child Posyandu at Ponowaren Sleman just monitoring growth, while development monitoring is only done if there is a visit fromCommunity Health Centre, because limited cadres who got TGDDtraining. The purpose of this TGDD Training is to improve the ability of cadres to be able to perform TGDD properly. Training methods include pre-post test training, $T G D D$ counseling, TGDD practice includes anthropometric measurements, Maternal and Child (MCH) Handbook utilization on Health Card, z-score table, Head Circle, interpretation of TGDD measurement results and counseling of MCH Handbook to be media of health education. The result of the training are the increase of knowledge level about the child's growth and development is evidenced by the increase of prepost test score as much as 10-30 point, 14 cadres were competent to doTGDD da have successfully 
practiced TGDD correctly MCH Handbook not only apply to growth simulation result but also report result detection of development and used to media of health education by cadres.

Keywords : Toddler, Growth, Development, Cadres

Submitted: 16 Mei 2018 Revision: 5 Juli 2018 Accepted : 17 Juli 2018

\section{PENDAHULUAN}

Masa lima tahun pertama kehidupan atau masa Balita yang merupakan masa paling peka dengan lingkungan dan disebut masa keemasan/ Golden age periode merupakan window of opportunity, masa kritis/ critical periodeyang sangat penting dan mempengaruhi kualitas hidup anak dikehidupan mendatang. Pada masa ini anak akan mengalami proses tumbuh kembang paling pesat, proses pertumbuhan sendiri akan mempengaruhi perkembangan anak selanjutnya (Depkes, 2010).

Pertumbuhan dasar pada balita akan mempengaruhi dan menentukan perkembangan anak selanjutnya. Terjadi perkembangan yang sangat cepat pada kemampuan berbahasa, kreativitas, sosial, emosional dan intelegensia yang merupakan landasan perkembangan berikutnya. Perkembangan moral serta dasardasar kepribadian juga dibentuk pada masa ini. Deteksi dini perkembangan anak dilakukan dengan cara pemeriksaan perkembangan secara berkala, apakah sesuai dengan umur atau telah terjadi penyimpangan dari perkembangan normal (Kania, 2006)

Pelayanan Deteksi Tumbuh Kembang Balita (DTKB) sangat penting dilakukan secara rutin dan berkelanjutankarena kelainan tumbuh kembang yang dideteksi secara dini akan mendapatkan intervensi yang sesuai sehingga akan meningkatkan keberhasilan intervensi yang diberikan. Kelainan tumbuh kembang yang terlambat dideteksi dan diintervensi dapat mengakibatkan kemunduran perkembangan anak dan berkurangnya efektivitas terapi sehingga mempengaruhi kualitas kehidupan anak mendatang.

Keterlambatan perkembangan umum atau global developmental delay merupakan keadaan keterlambatan perkembangan yang terjadi pada dua atau lebih ranah perkembangan. Sekitar 5 hingga $10 \%$ anak diperkirakan mengalami keterlambatan perkembangan. Data angka kejadian keterlambatan perkembangan umum belum diketahui dengan pasti, namun diperkirakan sekitar 1-3\% anak di bawah usia 5 tahun mengalami keterlambatan perkembangan umum. Keterlambatan perkembangan dapat diketahui dengan keluhan/ laporan orang tua dan pelaksanaan deteksi dini/ skrining perkembangan pada anak. Pemeriksaan skrining perkembangan sangat penting dilakukan untuk mrngetahui penyebab keterlambatan perkembangan sedini mungkin, sehingga dapat segera dialkukan intervensi yang tepat (Medise, 2013).

Posyandu merupakan salah satu bentuk pendekatan partisipasi masyarakat di bidang kesehatan yang dikelola oleh kader posyandu yang telah mendapatkan pelatihan dan pendidikan dari Puskesmas. Kader posyandu memiliki peran yang penting karena merupakan pihak yang berada di dekat kegiatan sasaran posyandu dan memiliki frekuensi tatap muka kader lebih sering daripada petugas kesehatan lainnya (Nugroho \& Nurdiana, 2008). Kader merupakan penggerak masyarakat untuk sadar akan kesehatan ibu dan anak, pada beberapa kasus keterlambatan tumbuh kembang, ibu hamil resiko tinggi, maupun masalah kesehatan sebagian besar dideteksi atau ditemukan sejak 
awal oleh kader(Kementerian Kesehatan RI, 2012b).

Hasil observasi di Posyandu Kuncup Mekar, kegiatan posyandu lebih banyak dilakukan dengan pemantauan pertumbuhan yaitu pengukuran tinggi/ panjang badan, berat badan dan pengukuran lingkar kepala balita. Sementara deteksi perkembangan tidak rutin dilakukan, pemeriksaan deteksi perkembangan dengan menggunakan Kuisioner Pra Skrining (KPSP) hanya dilakukan 3 bulansekali oleh tenaga dari Puskessmas saat dilakukan kunjungan. Baru terdapat satu kader yang pernah dilatih DTKB, sementara 13 lainnya belum pernah mengikuti pelatihan DTKB. Keterbatasan sumber daya inilah yang menjadi kendala pelaksanaan pemantauan perkembangantidak dilakukan oleh kader . Penggunaan buku KIA sendiri sangat terbatas pada pengisian KMS, sementara fungsi lain seperti penggunaan table z-score untuk deteksi stunting/ balita pendek, penggunaan buku KIA untuk media pendidikan kesehatan belum optimal.

\section{METODE KEGIATAN}

Pelatihan Deteksi Tumbuh Kembang diberikan kepada kader posyandu meliputi:

1. Pre test awal tentang pengetahuan tumbuh kembang anak, Penyuluhan Deteksi Tumbuh Kembang Balita (DTKB) dan membuat kesepakatan dengan kader terkait rundown pelatihan yang akan dilakukan.

2. Metode penyuluhan DTKB dilakukan dengan ceramah dengan menggunakan media power point, pemutaran video pemeriksaan tumbuh kembang anak, dan redemonstrasi pemeriksaan pertumbuhan menggunakan phantom bayi dan menggunakan alat yang terstandar, sedangkan redemonstrasi deteksi perkembangan dilakukan dengan bertanya langsung ke orang tua balita dan memberikan tugas pada balita sesuai dengan usianya.

3. Metode penyuluhan pemanfaatan Buku KIA dilakukan dengan menggunakan ceramah, diskusi Tanya jawab dan simulasi pemberian pendidikan kesehatan menggunakan media buku KIA, masing- masing kader diberikan buku KIA.

4. Penilaian DTKB dilakukan masing- masing kader dengan mempraktikkan pemeriksaan KPSP, masing- masing kader melakukan anamnesa dan KPSP pada balita sesuai dengan usia, pengukuran $\mathrm{BB}, \mathrm{TB} / \mathrm{PB}, \mathrm{LK}$ dilakukan dan dicatat dalam buku KIA. Setelah itu kader harus menyimpulkan hasil KPSP, pengukuran antropometri, mencatatkan hasil DTKB dalam buku KIA dan memberikan pendidikan kesehatan pada orang tua menggunakan buku KIA.

Pada akhir kegiatan masing- masing kader dilakukan post tes untuk mengukur pengetahuan pasca diberikan pelatihan

\section{HASIL DAN PEMBAHASAN}

Hasil Pre tes yang dilakukan pada kader, sebagian besar kader mendapatkan rentang skor 60-70, dari total 10 pertanyaan yang diberikan. Sebagian besar kader menjawab salah terkait pemantauan perkembangan pada balita. Menurut (Sices, 2007) deteksi perkembangan anak sangat penting dilakukan sedini mungkin untuk mendeteksi adanya keterlambatan perkembangan pada anak, kasus keterlambatan perkembangan yang ditemukan sejak dini dapat mempermudah intervensi yang diberikan dan meningkatkan keefektifitan terapi yang diberikan.

Beberapa kader yang mendapatkan skor pretest $<70$ sebelumnya belum pernah mengikuti pelatihan terkait DTKB, hal ini dikarenakan keterbatasan pihak Puskesmas Gamping yang hanya memberikan kesempatan pelatihan pada 1 kader tiap posyandu. Kader merupakan penghubung antara masyarakat dengan tenaga kesehatan karena selalu berada di tengah-tengah masyarakat dan pertama kali menemukan masalah kesehatan di daerahnya dan segera melaporkan ke tenaga kesehatan setempat, mengingat pentingnya peran kader dalam kesehatan masyarakat maka kader 
perlumengetahui tentang hal-hal yang berhubungan dengan masalah kesehatan anak (Kementrian Kesehatan RI, 2010) salah satunya dengan mengikuti pelatihan DTKB.

Hasil Penilaian DTKB, semua kader dapat melakukan deteksi guna perkembangan dengan KPSP dan deteksi pertumbuhan dengan pengukuran antropometri (Berat Badan, Tinggi Badan/ Panjang Badan, Pada evaluasi masingmasing kader harus melakukan anamnesa, dan mengajukan 10 pemeriksaan kepada balita/ menanyakan perkembangan anak kepada orang tua/ pengasuh sesuai dengan usia anak. Setelah melakukan KPSP kader harus melakukan interpretasi hasil dan menyampaikan hasil deteksi perkembangan pada orang tua/ pengasuh. KPSP bertujuan untuk mengetahui perkembanganseorang anak apakah sesuai dengan usianya ataukahditemukan kecurigaan penyimpangan (Kementerian Kesehatan RI, 2012b).

Deteksi pertumbuhan dilakukan dengan melakukan pengukuran $\mathrm{BB}, \mathrm{TB} / \mathrm{PB}$, serta $\mathrm{LD}$, setelah pengukuran kader harus memasukkan hasil pengukuran ke dalam buku KIA pada lembar KMS, Tabel Z-score, dan tabel LK serta harus dapat menginterpretasikan status gizi anak, apakah penambahan BB sesuai dengan kenaikan berat minimal (KMB), apakah anak pendek/ stunting, apakah LK anak normal/ tidak. Di Kabupaten Sleman terjadi kenaikan jumlah kasus stunting, hal tersebut salah satunya disebabkan karena pengukuran TB/PB yang kurang akurat. Di Posyandu Kuncup Mekar sendiri pengukuran PB bayi dilakukan dengan menggunakan pita meter sehingga hasil kurang akurat, hasil pengukuran tidak dimasukkan ke dalam table z-score. Pengukuran TB/PB idealnya dilakukan dengan menggunakan pita meter yang terstandar dan dilakukan minimal 2 orang, hasil pengukuran dibandingkan dengan tabel z-score (WHO, 2006)untuk menginterpretasikan kondisi stunting atau tidak.

Hasil Post tes yang dilakukan pada kader terjadi kenaikan nilai sebanyak 10-30 poin, hal tersebut membuktikan bahwa ada perbedaan tingkat pengetahuan setelah dilakukan pelatihan

\section{SIMPULAN}

1. Ada kenaikan pengetahuan tentang pertumbuhan dan perkembangan anak dibuktikan dengan kenaikan skor pada pre dan post tes, kenaikan nilai antara rentang 10-30 poin

2. Pelatihan DTKB pada kader telah dilaksanakan pada 14 kader dan telah dilakukan evaluasi, semua kader yang telah mengikuti pelatihan dapat melakukan DTKB dengan benar.

3. Penyuluhan pemanfaatan buku KIA telah dilakukan, kader diajarkan penggunaan buku KIA untuk deteksi pertumbuhan menggunakan lembar KMS, table Z-Score, dan tabel Lingkar Kepala (LK) serta cara interpretasi hasil pengukuran, kader juga diajarkan penggunaan buku KIA sebagai media pendidikan kesehatan.

\section{DAFTAR PUSTAKA}

Depkes. (2010). Pedoman Kader Seri Kesehatan Anak. Direktorat Bina Kesehatan Anak Kementerian Kesehatan RI.

Kania, N. (2006). Stimulasi Tumbuh Kembang Anak Untuk Mencapai Tumbuh Kembang Yang Optimal, Artikel, Disampaikan pada seminar "Stimulasi Tumbuh Kembang Anak" Bandung, 11 Maret 2006.

Kemenkes. (2012). Pedoman Pelaksanaan Stimulasi Deteksi Intervensi Dini Tumbuh Kembang Anak di Tingkat Pelayanan Kesehatan Dasar. Jakarta: Departemen Kesehatan RI.

Kementrian Kesehatan RI. (2010). Pedoman Kader Seri Kesehatan Anak. Jakarta.

Nugroho, H., \& Nurdiana, D. (2008). Hubungan Antara Pengetahuan dan Motivasi Kader Posyandu dengan Keaktifan Kader Posyandu di Desa Dukuh Tengah Kecamatan Ketanggungan Kabupaten Brebes. Jurnal Keperawatan, 2(1), 1-8. 
Sices, L. (2007). Developmental Screening In

Primary Care: The Effectiveness Of

Current Practice And Recommendations

For Improvement Laura Sices Boston

Medical Center / Boston University School

of Medicine December 2007, (1082).

Retrieved from

www.commonwealthfund.org.

WHO. (2006). WHO Child Growth Standards. Geneva: Wordl Health Organization. 